\title{
Dynamics and underlying causes of illegal bushmeat trade in Zimbabwe
}

\author{
P. A. Lindsey, S.S. RomañaCh, S. Matema, C. Matema, I. Mupamhadzi and \\ J. MUVENGWI
}

\begin{abstract}
The prevalence and impacts of the illegal trade in bushmeat are under appreciated in Southern Africa, despite indications that it constitutes a serious conservation threat in parts of the region. Bushmeat trade has emerged as a severe threat to wildlife conservation and the viability of wildlife-based land uses in Zimbabwe during a period of political instability and severe economic decline. We conducted a study around Savé Valley Conservancy in the South-East Lowveld of Zimbabwe to investigate the dynamics and underlying causes of the bushmeat trade, with the objective of developing solutions. We found that bushmeat hunting is conducted mainly by unemployed young men to generate cash income, used mostly to purchase food. Bushmeat is mainly sold to people with cash incomes in adjacent communal lands and population centres and is popular by virtue of its affordability and availability. Key drivers of the bushmeat trade in the South-East Lowveld include: poverty, unemployment and food shortages, settlement of wildlife areas by impoverished communities that provided open access to wildlife resources, failure to provide stakes for communities in wildlife-based land uses, absence of affordable protein sources other than illegally sourced bushmeat, inadequate investment in anti-poaching in areas remaining under wildlife management, and weak penal systems that do not provide sufficient deterrents to illegal bushmeat hunters. Each of these underlying causes needs to be addressed for the bushmeat trade to be tackled effectively. However, in the absence of political and economic stability, controlling illegal bushmeat hunting will remain extremely difficult and the future of wildlife-based land uses will remain bleak.
\end{abstract}

P. A. LindSEY (Corresponding author) Mammal Research Institute, Department of Zoology and Entomology, University of Pretoria, Pretoria 0002, South Africa, TRAFFIC East/Southern Africa, PO Box CY1409, Causeway, Harare, Zimbabwe, and African Wildlife Conservation Fund, 10564 NW 57th Street, Doral, FL33178, USA. E-mail palindsey@gmail.com

S.S. RomañACH African Wildlife Conservation Fund, Doral, USA

S. Matema and C. Matema Centre for Applied Social Sciences, University of Zimbabwe, Harare, Zimbabwe

I. MupamhadZI TRAFFIC East/Southern Africa c/o WWF-Southern Africa Regional Programme Office, Harare, Zimbabwe

J. Muvengwi Department of Environmental Science, Bindura University of Science Education, Bindura, Zimbabwe

Received 4 July 2009. Revision requested 7 September 2009.

Accepted 16 December 2009.
Keywords Bushmeat, game ranching, land reform, private land, Savé Valley Conservancy, snaring, trade, Zimbabwe

This paper contains supplementary material that can be found online at http://journals.cambridge.org

\section{Introduction}

T unting and the sale of bushmeat represent an impor1 tant survival strategy for significant numbers of people in rural forest areas of West and Central Africa (Bowen-Jones et al., 2003). In some places bushmeat is a relatively high-value luxury commodity that flows primarily from rural sources to urban areas (Bowen-Jones \& Pendry, 1999; Fa et al., 2000). In rural areas bushmeat is often an important alternative protein source to meat from livestock, particularly where tsetse flies (Glossina spp.) are prevalent (Barnett, 1998).

The scale of the bushmeat trade in some Central and West African nations is such that it contributes measurably to gross domestic products (Bowen-Jones et al., 2003). However, the bushmeat trade is commonly unsustainable, as reflected by declining prevalence of large species in markets and increasing reliance on $\mathrm{r}$-selected species ( $\mathrm{Fa}$ et al., 2000). Rates of offtake are such that widespread local extinctions of forest species are likely (Wilkie \& Carpenter, 1999). Finding solutions to reduce reliance on this unsustainable harvest is thus important from the perspective of both wildlife conservation and human needs.

The majority of work on bushmeat consumption and trade in Africa has focused on the forest regions of West and Central Africa (Noss, 1998; Wilkie et al., 1998; Bowen-Jones \& Pendry, 1999; Fa et al., 2000; Barnes, 2002; Robinson \& Bennett, 2004; Bennett et al., 2007). Outside these areas research on bushmeat has been limited largely to studies in East Africa, notably around the Serengeti (Loibooki et al., 2002; Ndibalema \& Songorwa, 2007) and in parts of Kenya (Fitzgibbon et al., 1995; Okello \& Kiringe, 2004; Wato et al., 2006).

TRAFFIC conducted a review of the bushmeat trade in Southern Africa in the late 1990s (Barnett, 1998), and there has been some work on the topic in Zambia (Lewis, 2007) and Namibia (Vaughn \& Long, 2007). Otherwise, there has been little attention to the issue in Southern Africa, perhaps because of a misconception that bushmeat hunting is a sustainable subsistence phenomenon in the region (Barnett, 
1998). There are indications that the bushmeat trade is a serious threat to conservation in parts of Southern Africa (Lewis \& Phiri, 1998; du Toit, 2004). Commercialized trade involving meat sourced from protected areas occurs in at least five Southern African nations (Barnett, 1998).

The prevalence and impacts of the bushmeat trade appear to be exacerbated under conditions of economic and political instability (de Merode \& Cowlishaw, 2006). For example, in Mozambique during and following the civil war (1977-1992) wildlife populations were decimated by bushmeat hunters (Hatton et al., 2001). In Tanzania a significant illegal trade in bushmeat arose as a result of the influx of refugees from neighbouring Burundi, the Democratic Republic of Congo and Rwanda (Jambiya et al., 2007). In the Democratic Republic of Congo the prevalence of protected species in urban markets increased during civil war (de Merode \& Cowlishaw, 2006).

In Zimbabwe economic decline, political instability and the settlement of private game ranches and parts of Gonarezhou National Park have created conditions conducive to unsustainable bushmeat trade (du Toit, 2004). These settlements occurred during so-called land reform, in which white-owned farms were settled with subsistence farming communities or seized by prospective black commercial farmers. Where game ranches were occupied by communities, land use shifted from wildlife to subsistence farming, creating mosaics of wildlife habitat and human settlement (Lindsey et al., 2008). The land reform programme severely disrupted agriculture, tourism and their support industries and contributed directly to nine consecutive years of recession, $>80 \%$ unemployment, $80 \%$ of the population living under the poverty line, collapse of the currency, acute food shortages and increased dependency among rural communities on natural resources for survival (Coltart, 2008; Hanke, 2009).

Using Savé Valley Conservancy in the South-East Lowveld of Zimbabwe (Fig. 1 in Lindsey et al., 2011) as a case study, we researched the nature, dynamics and underlying causes of the illegal bushmeat trade. This Conservancy is a privately owned wildlife area of $3,450 \mathrm{~km}^{2}$, comprising 11 management units with multiple owners/lessees. Primary land uses are regulated safari hunting and photographic tourism. During $2000-2001$ c. $33 \%$ of the Conservancy was occupied by subsistence farmers following land reform, during which c. $80 \mathrm{~km}$ of perimeter game fencing was removed. The basis for selection of ranches for resettlement is not entirely clear but appears to have been driven by a combination of historical land claims, the presence of attractive infrastructure (such as dams) and opportunism on the part of people occupying land when such occupations were supported by the ruling political party.

This article complements Lindsey et al. (2011), who examine the ecological and financial impacts of illegal hunting, demonstrating that the phenomenon threatens the sustainability of wildlife-based land uses. Wildlife populations in the settled parts of wildlife areas in the South-East Lowveld have been virtually eradicated by illegal bushmeat hunting and are declining in adjacent areas (Lindsey et al., 2011).

In Savé Valley Conservancy illegal hunting is conducted without consent of the land owner (although on resettled land, the concept of land ownership is blurred), is not based on quotas approved by the Parks and Wildlife Management Authority, frequently involves prohibited hunting methods (snares), and typically concludes with the unauthorized sale of meat, and is thus illegal according to the Parks and Wildlife Act (1975), the Trapping of Animals (Control) Act (2002) and Statutory Instrument 26 (1998). In contrast, safari hunting tourism is conducted legally in the Conservancy based on quotas allocated to each ranch on a per capita basis, following approval by the Parks and Wildlife Management Authority.

\section{Methods}

\section{Questionnaire surveys}

Structured interview surveys were conducted with three groups of respondents: (1) illegal hunters (i.e. people hunting illegally), (2) bushmeat buyers and (3) ranchers in Savé Valley Conservancy (Appendices 1-3). Respondents were informed that the surveys would be anonymous and were part of a university study investigating wildlife and rural livelihoods. All surveys were conducted in the home language of the respondents (Chi-Shona or English) and by trained interviewers of the same ethnic group (four black Chi-Shona interviewers or one white English-speaking Zimbabwean). Interviewers were trained in survey techniques and provided with multiple opportunities to practice questionnaires under supervision. This process ensured that all queries were resolved, the questionnaire was thoroughly pre-tested and standardized interview procedure was adopted by all interviewers.

Illegal hunters and bushmeat buyers In mid 2006 illegal hunters and meat buyers were interviewed in the five population centres closest to Savé Valley Conservancy (Birchenough Bridge, Checheche, Chibuwe, Chiremwaremwa and Mkwasine). The clandestine nature of illegal hunting precluded randomized sampling: assistants living in the sample areas introduced interviewers to known hunters within the community. Additionally, illegal hunters captured by scouts in the Conservancy were interviewed before being transferred to the police. Bushmeat buyers were sampled systematically in each of the five population centres by interviewing the head of the household in every fifth house on the main street(s) in the population centre. 
A second survey of illegal hunters and buyers (involving different respondents) was conducted at the same study sites in mid 2008 to gain further details of the nature of the bushmeat trade using the same methods for respondent selection. The second survey also included illegal hunters and buyers randomly sampled from communities that settled in the Conservancy following land reform. Seven of the nine ranches settled during land reform were randomly selected and community members who settled on those properties were interviewed using the same methods for respondent selection as used in the sample sites outside the Conservancy.

Ranchers The owners or managers of all ranches in Save Valley Conservancy were interviewed. In addition to the data gathered from the rancher survey, ranchers were also asked to provide data on the outcome of the criminal proceedings against illegal hunters (as that information accrued to them from the police). The potential legal production of game meat from ranches in the Conservancy was estimated based on legal hunting offtakes for 2007 (obtained from the Conservator), and indications from ranchers regarding the way they currently utilize game meat and the amount they would be willing to contribute at a subsidized price for a meat distribution scheme for adjacent communities. Current safari hunting quotas are unsustainable because of high illegal offtake (Lindsey et al., 2011). Two estimates of potential meat production were made, given quota reductions based on (1) conservative estimates of losses to illegal hunting (i.e. from the records of anti-poaching teams) and (2) more realistic estimates of losses (based on recorded losses plus ranchers' estimates of additional incidents that occur without being detected by anti-poaching teams; rationale presented in Lindsey et al., 2011).

Data on the human population were required to estimate potential meat provision per person in the communities adjacent to the Conservancy. Latest available estimates (from 1994) suggest that human densities neighbouring the Conservancy are $11-82 \mathrm{~km}^{-2}$ (Pole, 2006). Uncertainty exists regarding recent population trends in Zimbabwe and estimates for 2008 vary from 8 to 11.3 million (The Independent, 2006; CIA, 2008). Three scenarios of human population density are presented in which the population in the Conservancy area is adjusted proportionately assuming that the national population has (1) declined to 8 million from 11.5 million in 1994 (FAO, 2009), (2) declined to 11.3 million and (3) increased at the rate (1.5\%) estimated by UNICEF (2009) for 1990-2006, since 1994.

\section{Statistical analyses}

Survey data were analysed using multiple logistic regression, $\chi^{2}$ tests and analyses of variance, as appropriate (JMPIN, 2000). For logistic regression results are presented as $\chi^{2}$ values for the whole model (with only significant variables included following a backwards stepwise procedure). Statistical comparisons of data obtained from captive vs free hunters were made using multiple logistic regression, $\chi^{2}$ tests and analyses of variance as appropriate; where differences emerged, data from captive hunters were discarded. All data from captive hunters from questions that may have been perceived to have been incriminating, such as those concerning hunting history and future intentions regarding hunting, were discarded. Responses from the first and second round of surveys were compared statistically using multiple logistic regression, $\chi^{2}$ tests and analyses of variance, as appropriate and, where no differences were detected, data were combined; otherwise, data from the latest survey are presented.

During the period of the study there was a discrepancy between the official (controlled) exchange rate for the ZWD (published by the Reserve Bank) and the actual exchange rate used by most people when changing currency (the 'parallel' rate). Daily parallel market exchange rates were obtained from Harare-based currency traders and were used to estimate the USD value of ZWD transactions.

\section{Results}

\section{Illegal hunter and buyer profiles}

A total of 318 illegal hunters and 391 buyers were interviewed. People in $75.9 \%$ of households approached buy bushmeat. Interviewees were willing to participate in the interviews (refusal rates: hunters, 5.4\%; buyers, 3.0\%) and answered questions freely. Refusal rates $<10 \%$ are not considered to be problematic in terms of non-response bias (Lindner, 2002).

Buyers were generally older and wealthier than hunters. Hunters were typically in their late 20 s and early 30 s, unemployed, with low monthly income, low levels of livestock ownership and poor food security (Table 1). Compared to hunters and buyers living outside Savé Valley Conservancy, hunters and buyers living inside were less educated $(7.79 \pm \mathrm{SE} 0.82$ vs $8.39 \pm \mathrm{SE} 0.14$ years of schooling ), had more children drop out of school (0.65 \pm SE 0.07 year $^{-1}$ vs $0.52 \pm$ SE 0.05 ) and were less likely to hold a position of influence in the community (3.1\% vs $12.7 \%)$ but were more likely to be in possession of livestock $(60.5 \%$ vs $30.7 \%$; multiple logistic regression, $\chi^{2}=56.2, \mathrm{df}=7, \mathrm{P}<$ 0.001; JMPIN, 2000). Respondents inside the Conservancy also had lower crop yields (10.7 \pm SE 1.3 bags of sorghum/ maize vs $13.0 \pm \mathrm{SE} 0.85$ ), were less likely to be employed (9.65\% vs $16.5 \%$ ) and their children more likely to have to skip meals (90.2\% vs $76.2 \%$ ) and although these differences were not statistically significant, when these variables were included the whole model was significant, $\chi^{2}=38.8, \mathrm{df}=8$, $\mathrm{P}<0.001$; JMPIN, 2000). Respondents living inside the Conservancy had various origins prior to their settlement 
TABLE 1 Details of personal characteristics, education, social standing, whether employed, income, indicators of food security, livestock ownership and household of illegal hunters and bushmeat buyers, and statistical comparisons between the two groups.

\begin{tabular}{|c|c|c|c|}
\hline Personal characteristics & $\begin{array}{l}\text { Illegal hunters } \\
(\mathrm{n}=318)\end{array}$ & $\begin{array}{l}\text { Bushmeat buyers } \\
(\mathrm{n}=391)\end{array}$ & Statistical comparison \\
\hline Gender & $100 \%$ male & $58.0 \%$ male & $\chi^{2}=635.6, \mathrm{df}=1, \mathrm{P}<0.001$ \\
\hline Age (years, mean \pm SE) & $31.1 \pm 0.66$ & $41.3 \pm 0.69$ & $\mathrm{df}=1, F=64.1, \mathrm{P}<0.001$ \\
\hline$<20$ & $11.0 \%$ & $1.3 \%$ & \\
\hline $20-29$ & $43.4 \%$ & $20.1 \%$ & \\
\hline $30-39$ & $28.3 \%$ & $31.1 \%$ & \\
\hline $40-49$ & $8.8 \%$ & $20.3 \%$ & \\
\hline$>50$ & $8.5 \%$ & $27.2 \%$ & \\
\hline Education (continuous years, mean \pm SE) & $7.62 \pm 0.53$ & $8.75 \pm 0.20$ & $\mathrm{df}=1, F=12.4, \mathrm{P}<0.001$ \\
\hline $\begin{array}{l}\text { Holding position of responsibility within } \\
\text { community }\end{array}$ & Not measured & $19.4 \%$ & \\
\hline Employed & $11.2 \%$ & $21.2 \%$ & $\chi^{2}=9.05, \mathrm{df}=1, \mathrm{P}<0.001$ \\
\hline Total monthly income (USD, mean \pm SE) & $10.4 \pm 1.44$ & $51.0 \pm 13.4$ & $\mathrm{df}=1, F=20.7, \mathrm{P}<0.001$ \\
\hline Had to skip meals in last 12 months & $93.8 \%$ & $88.4 \%$ & $\chi^{2}=27.9, \mathrm{df}=2, \mathrm{P}<0.001$ \\
\hline Children had to skip meals in last 12 months & $71.6 \%$ & $88.5 \%$ & $\chi^{2}=27.9, \mathrm{df}=2, \mathrm{P}=0.004$ \\
\hline Own livestock & $28.3 \%$ & $56.8 \%$ & $\chi^{2}=58.3, \mathrm{df}=1, \mathrm{P}<0.001$ \\
\hline Total livestock owned (mean \pm SE) & $3.81 \pm 0.62$ & $7.76 \pm 0.68$ & $\mathrm{df}=1, F=22.4, \mathrm{P}<0.001$ \\
\hline Cattle (mean \pm SE) & $1.45 \pm 0.23$ & $2.94 \pm 0.41$ & \\
\hline Goats (mean $\pm \mathrm{SE})$ & $2.29 \pm 0.21$ & $3.87 \pm 0.35$ & \\
\hline Sheep (mean \pm SE) & $0.07 \pm 0.06$ & $0.72 \pm 0.14$ & \\
\hline Donkeys (mean \pm SE) & $0.13 \pm 0.05$ & $0.26 \pm 0.07$ & \\
\hline Livestock sold in preceding year (mean \pm SE) & $0.21 \pm 0.06$ & $0.98 \pm 0.24$ & $\mathrm{df}=1, F=8.07, \mathrm{P}<0.004$ \\
\hline $\begin{array}{l}\text { Livestock slaughtered in preceding year } \\
\quad(\text { mean } \pm \mathrm{SE})\end{array}$ & $0.30 \pm 0.07$ & $1.09 \pm 0.33$ & $\mathrm{df}=1, F=4.98, \mathrm{P}<0.026$ \\
\hline No. of people in household (mean \pm SE) & $6.45 \pm 0.23$ & $7.64 \pm 0.25$ & $\mathrm{df}=1, F=11.6, \mathrm{P}<0.001$ \\
\hline No. of children at school (mean \pm SE) & $1.95 \pm 0.14$ & $1.67 \pm 0.11$ & $\mathrm{df}=1, F=5.95, \mathrm{P}=0.015$ \\
\hline $\begin{array}{l}\text { No. of children that dropped out of school in } \\
\text { preceding year (mean } \pm S E)\end{array}$ & $1.75 \pm 0.13$ & $0.32 \pm 0.83$ & $\mathrm{df}=1, F=16.6, \mathrm{P}<0.001$ \\
\hline
\end{tabular}

${ }^{\star}$ For example business leader, agricultural coordinator, village headman or chairman

there, from seven districts (Bikita 29.6\%, Chipinge 46.8\%, Chiredzi 17.4\%, Chivu 0.9\%, Gutu 3.5\%, Gwanda 0.9\%, Mwenezi $0.9 \%$ ) and a total of 25 locations within those districts.

\section{Illegal hunters}

Illegal hunters used snares (56.3\%), dogs (50.1\%), snares and dogs (i.e. where some snares are set whilst hunting with dogs and then revisited by the hunter later, $7.8 \%$ ) and spears (2.3\%). Hunters obtained wire for snares by stealing it from the Savé Valley Conservancy fence $(57 \%)$, gardens or farms $(25.0 \%)$ or telephone lines (3.8\%). Illegal hunters selected hunting areas based on proximity to home (40\%), abundance of wildlife (37.0\%), levels of security $(8.7 \%)$ and availability of preferred species $(7.7 \%)$. Hunters using dogs selected hunting sites based on proximity to home (29.0\%), wildlife abundance (24.3\%), abundance of preferred species $(21.1 \%)$ and anti-poaching security (10.9\%).

A greater proportion of illegal hunters incurred costs and fewer received benefits from wildlife in the Conservancy than buyers $\left(\chi^{2}=24.2, \mathrm{df}=2, \mathrm{P}<0.001\right.$; Table 2$)$. Illegal hunters and buyers living within the Conservancy received fewer benefits and incurred more costs than those living outside it $\left(\chi^{2}=63.4, \mathrm{df}=2, \mathrm{P}<0.001\right)$.

Illegal hunters sold $74.4 \% \pm$ SE 0.01 of the bushmeat they obtained in the Conservancy in 2008. Income from selling bushmeat was used to purchase food ( $96.7 \%$ of respondents) and clothes (43.5\%), pay school fees (22.6\%) or purchase beer (15\%). Twenty-seven percent of illegal hunters always sold meat for cash and $71.0 \%$ sometimes sold for cash and sometimes bartered. Most (71.0\%) respondents sold meat that was not dried. Selling meat takes $14.4 \pm$ SE 1.78 hours to sell after a hunting trip (range: 1-72), for a mean price of USD $0.39 \pm$ SE $0.04 \mathrm{~kg}^{-1}$. Illegal hunters earned a mean of USD $8.19 \pm$ SE 0.61 per month from selling meat, equating to the sale of $21.0 \mathrm{~kg} \mathrm{month}^{-1}$. The sale of bushmeat comprised $78.6 \%$ of the monthly cash income of illegal hunters (Table 1 ). All illegal hunters sold meat at settlements developing around infrastructure, such as road intersections, settlement compounds, schools or communal lands within $10 \mathrm{~km}$ of the Conservancy. A minority (23.2\%) also sold meat at more distant $(60-400 \mathrm{~km})$ urban centres. When selling bushmeat $30.4 \%$ of hunters would lie about the type of meat on sale, most commonly when trying to sell meat from lions Panthera leo or other carnivores $(65.8 \%$ of respondents 
TABLE 2 Percentages of illegal hunters and bushmeat buyers receiving benefits, or incurring costs, from Savé Valley Conservancy (SVC) or its wildlife inside and outside the Conservancy.

\begin{tabular}{|c|c|c|c|c|}
\hline & \multicolumn{2}{|c|}{ Illegal hunters $(\mathrm{n}=318)$} & \multicolumn{2}{|c|}{ Bushmeat buyers $(\mathrm{n}=391)$} \\
\hline & Inside & Outside & Inside & Outside \\
\hline \multicolumn{5}{|l|}{ Benefits } \\
\hline Receive any benefits & 0 & 4.5 & 5.3 & 28.4 \\
\hline Firewood & 0 & 0 & 0 & 1.1 \\
\hline Building materials & 0 & 1.8 & 0 & 18.9 \\
\hline Hides & 0 & 0.9 & 0 & 2.1 \\
\hline Assistance with irrigation & 0 & 0 & 0 & 2.1 \\
\hline School built by SVC & 0 & 0 & 0 & 0 \\
\hline \multicolumn{5}{|l|}{ Costs } \\
\hline Incur any costs & 88.2 & 69.1 & 72.9 & 33.3 \\
\hline Elephant crop damage & 58.8 & 66.4 & 64.6 & 46.2 \\
\hline Baboon crop damage & 47.1 & 30.0 & 18.0 & 20.4 \\
\hline Livestock loss to predators & 5.9 & 10.1 & 5.2 & 3.2 \\
\hline Risk to human life from wildlife & 5.9 & 12.7 & 3.1 & 1.1 \\
\hline
\end{tabular}

indicating that they lie) or baboons Papio cynocephalus $(60.5 \%)$. Over one third (38.5\%) of hunters had consumed bushmeat during the previous 24 hours and ate bushmeat more frequently $\left(1.48 \pm\right.$ SE 0.17 times week $\left.^{-1}\right)$ than other proteins (e.g. fish $0.36 \pm \mathrm{SE} 0.09$ times week $^{-1}$, milk $0.17 \pm \mathrm{SE}$ 0.5 , beef $0.16 \pm \mathrm{SE} 0.04$, chicken $0.14 \pm \mathrm{SE} 0.03$, goat $0.12 \pm \mathrm{SE}$ $0.03)$.

Respondents' intention to hunt again in the Conservancy was not influenced by whether they had a job (will hunt again, $12.6 \%$ employed, and will not hunt again, $4.17 \%$ employed) or their monthly income (will hunt again, USD 10.5 \pm SE 1.81, and will not hunt again, USD 10.6 \pm SE 2.28). However, a lower percentage of respondents who plan to hunt again in the Conservancy own livestock (22.7\%) than respondents who do not plan to hunt again (45.8\%; $\left.\chi^{2}=5.75, \mathrm{df}=1, \mathrm{P}=0.019\right)$. Overall, $89 \%$ of illegal hunters planned to hunt in the Conservancy again because of poverty/the country's economic situation $(50.0 \%)$, unemployment (39.8\%) or food shortages (23.4\%).

Increasing the number of scouts and giving or selling cheap bushmeat to communities were the most commonly suggested means for the Conservancy to reduce illegal hunting $(51.4 \%$ and $40.0 \%$, respectively, of respondents). However, most hunters felt that if the Conservancy were to sell elephant Loxodonta africana meat (93.0\%) or other wild meat (97.6\%) to communities at the same price as meat in butcheries, their ability to sell meat would not be impaired because it would be cheaper, they would lower their prices to undercut the legal supply (86.6\%) and because many people do not eat elephant meat (21.4\%).

Illegal hunters considered the quality of security to vary among ranches in the Conservancy (Table 3). Forty-seven percent of hunters indicated they received illicit assistance from anti-poaching game scouts through advice on where to hunt $(54.9 \%)$, permission to hunt following payment of a bribe $(22.0 \%)$ or engaging in partnerships for hunting or selling meat $(13.7 \%)$.
Arrested hunters were most commonly punished with the option of a fine or a jail sentence (Table 4 ). The value of fines imposed on illegal hunters (mean: USD $2.81 \pm$ SE 0.71) was lower than their mean monthly earnings from selling bushmeat (USD $8.19 \pm \mathrm{SE} 0.61$ per month, $\mathrm{df}=1, F=3.38$, $\mathrm{P}=0.063$ ) and less than the value of meat from one impala Aepyceros melampus (USD 10.1, assuming meat price of USD 0.39 and a dressed weight of $26.1 \mathrm{~kg}$; Bothma, 2002). The severity of fines declined during 2005-2007 (USD $7.05 \pm$ SE 1.98 to USD $0.60 \pm$ SE 0.11 ), although jail sentences increased from $95.8 \pm$ SE 6.64 days in 2005 to $205 \pm$ SE 45.2 days in 2007. Jail sentences handed to hunters who had been caught before were longer than those granted to individuals without a previous conviction (mean: $183.7 \pm$ SE 47.0 days vs $93.5 \pm \mathrm{SE} 5.68, \mathrm{df}=1, F=3.86, \mathrm{P}=0.058$ ) and optional fines were higher (mean: USD $2.02 \pm \mathrm{SE} 0.45$ vs USD $0.26 \pm \mathrm{SE} 0.11, \mathrm{df}=1, F=4.62, \mathrm{P}=0.043)$.

\section{Buyers}

Ninety-eight percent of respondents purchased bushmeat from illegal hunters for personal consumption and the remainder to resell. Buyers purchased $2.62 \pm \mathrm{SE} 0.40 \mathrm{~kg}$ transaction $^{-1}$ and purchased meat every $38.5 \pm$ SE 2.6 days (corresponding to $18 \mathrm{~kg}$ year $^{-1}$ ); $11.6 \%$ of buyers had consumed bushmeat during the previous 24 hours. Respondents ate bushmeat more frequently ( $0.78 \pm \mathrm{SE} 0.12$ times week $^{-1}$ ) than other proteins (milk $0.68 \pm \mathrm{SE} 0.13$, chicken $0.46 \pm \mathrm{SE} 0.07$, beef $0.16 \pm \mathrm{SE} 0.07$, fish $0.23 \pm \mathrm{SE}$ 0.06 , goat $0.23 \pm$ SE 0.06 ).

Seventy-five percent of buyers prefer bushmeat over meat from domestic animals because it is cheaper (69\%), tastier $(50.0 \%)$ and adds variety (12.6\%). Buyers prefer impala (83.3\% of respondents), kudu Tragelaphus strepsiceros (67.7\%), warthog Potamochoerus porcus (24.0\%), buffalo Syncerus caffer (18.8\%) and eland Taurotragus oryx (16.7\%). Seventy-one percent (71.2\%) identified the species 
TABLE 3 Percentages of illegal hunters identifying ranches within Savé Valley Conservancy as having the best or worst security, and an indication of the investment made by each property owner in anti-poaching.

\begin{tabular}{lccc}
\hline & $\begin{array}{l}\text { \% identifying ranch } \\
\text { as having worst } \\
\text { security }\end{array}$ & $\begin{array}{l}\text { \% identifying } \\
\text { ranch as having } \\
\text { best security }\end{array}$ & $\begin{array}{l}\text { Investment } \\
\text { in anti-poaching } \\
\left(\mathrm{USD}_{\mathrm{km}}^{-2} \mathrm{month}^{-1}\right)^{1}\end{array}$ \\
\hline Chishakwe & 1.85 & 0 & 9.40 \\
Gunundwe & 4.63 & 1.43 & 0.75 \\
Hammond block & 5.56 & 13.6 & 2.55 \\
Humani block & 6.48 & 44.3 & 8.81 \\
Impala & 0 & 0 & 7.97 \\
Mapari/Msaize block & 2.78 & 5.0 & 1.99 \\
Masapas & 25.9 & 0 & 0.23 \\
Matendere & 1.85 & 0 & 2.96 \\
Mokore block & 17.59 & 0.71 & 2.33 \\
Potential & 16.7 & 0 & $0.23^{2}$ \\
Sango & 7.41 & 21.4 & 2.18 \\
Senuko block & 9.26 & 13.6 & 9.79 \\
\hline
\end{tabular}

${ }^{1}$ Derived from Lindsey et al. (2011)

${ }^{2}$ Expenditure data for potential ranch (a government parastatal) not available. From personal discussions with the poorly paid and poorly equipped antipoaching game scouts working there it is likely to be minimal (and so was arbitrarily granted a value equal to the lowest other ranch).

being sold through the appearance/colour of the meat and $13.0 \%$ by requesting to see a piece of the carcass and $3.5 \%$ by asking the seller. Buyers most commonly suggested that the best way for the Conservancy to reduce illegal hunting would be through the provision of cheap or free bushmeat to adjacent communities ( $81 \%)$, the employment of more scouts $(52.6 \%)$ and the provision of assistance to communities for infrastructure development (17.1\%).

When asked whether they would buy from a legal supply of frozen elephant meat sold on the boundaries of the Conservancy at a price equal to that of meat in butcheries, $89.5 \%$ of buyers said that they would not because the price would be too high (70.0\%) or because of an unwillingness to eat elephant meat for religious reasons $(17.6 \%)$.

\section{Ranchers}

Managers from all 15 ranches in Savé Valley Conservancy were interviewed (refusal rate $=0 \%$ ). Illegal hunting in the Conservancy was considered to be a significant problem by $57.1 \%$ of ranchers. Most ranchers $(80.0 \%)$ indicated that illegal hunting has not always been a significant problem. Most ranchers (80.0\%) indicated that the onset of largescale bushmeat hunting coincided with settlement associated with land reform in 2000-2001. Most ranchers considered areas close to the original boundaries of the Conservancy ( $60 \%$ of respondents) or close to the areas settled following the land seizures $(87.5 \%$ of ranches adjacent to settled areas) to be worst affected. All ranchers thought that meat extracted illegally from the Conservancy was sold at locations within $10 \mathrm{~km}$ of the boundary. Some $(35.4 \%)$ also felt that meat was sold at more distant urban centres $(27-113 \mathrm{~km})$. Ranchers suggested that the most effective means of reducing illegal hunting would be through the introduction of harsher sentences for illegal hunting (72.7\%), improved salaries for scouts (26.7\%) and provision of free or cheap game meat to neighbouring communities (20.0\%).

Approximately 215,000 $\mathrm{kg}$ of meat is produced from safari hunting in the Conservancy, of which ranchers indicated they would be willing to provide $36,500 \mathrm{~kg}$ at current quotas at a subsidized price for distribution to local

Table 4 Punishments handed by the courts to illegal hunters arrested in Savé Valley Conservancy $(\mathrm{n}=272)$.

\begin{tabular}{|c|c|c|}
\hline Punishment & $\%$ of accused & $\begin{array}{l}\text { USD value of fine at parallel market exchange } \\
\text { rate/length of sentence }\end{array}$ \\
\hline Optional fine or a jail sentence & 27.9 & USD $2.56 \pm$ SE $0.37 / 14.1 \pm$ SE 1.62 days \\
\hline Community service & 16.2 & $100 \pm$ SE 11.6 hours \\
\hline Jail sentence & 12.5 & $118 \pm$ SE 10.9 days \\
\hline Fine & 10.7 & USD $2.81 \pm$ SE 0.71 \\
\hline $\begin{array}{l}\text { Jail sentence or suspended jail sentence, } \\
\text { plus community service }\end{array}$ & 9.9 & $\begin{array}{l}100 \pm \text { SE } 6.24 \text { days/56.6 } \pm \text { SE 9.4/187 } \pm \text { SE } \\
67 \text { hours }\end{array}$ \\
\hline Warning & 4.0 & \\
\hline Suspended jail sentence & 3.7 & $75.7 \pm$ SE 6.19 days \\
\hline
\end{tabular}


TABLE 5 Estimated populations of 18 mammal species legally hunted, number of males shot, percentage of population hunted, and estimated yields of meat based on mean male mass and dressed percentage of animal from legal hunting in Savé Valley Conservancy in 2007.

\begin{tabular}{|c|c|c|c|c|c|c|}
\hline Species & $\begin{array}{l}\text { Population } \\
\text { size }\end{array}$ & Males shot & $\begin{array}{l}\% \text { of population } \\
\text { hunted }\end{array}$ & $\begin{array}{l}\text { Mean male } \\
\text { mass }(\mathrm{kg})^{1,2}\end{array}$ & $\%$ dressed $^{1}$ & $\begin{array}{l}\text { Meat yield } \\
(\mathrm{kg})\end{array}$ \\
\hline Buffalo Syncerus caffer & 1,744 & 70 & 4.01 & 650 & 50 & 22,750 \\
\hline $\begin{array}{l}\text { Bush buck Tragelaphus } \\
\text { scriptus }\end{array}$ & $?$ & 55 & $?$ & 60 & 55 & 1,815 \\
\hline $\begin{array}{l}\text { Bush pig } \\
\quad \text { Potamochoerus porcus }\end{array}$ & $?$ & 39 & $?$ & 62 & 61 & 1,475 \\
\hline $\begin{array}{l}\text { Grey duiker Sylvicapra } \\
\text { grimmia }\end{array}$ & $?$ & 18 & $?$ & 17 & 61 & 187 \\
\hline $\begin{array}{l}\text { Eland Taurotragus } \\
\text { oryx }\end{array}$ & 1,785 & 58 & 3.25 & 650 & 51 & 19,227 \\
\hline $\begin{array}{l}\text { Elephant Loxodonta } \\
\text { africana }\end{array}$ & 1,357 & 3 & 0.22 & 5,500 & 33 & 5,445 \\
\hline $\begin{array}{l}\text { Giraffe Giraffa } \\
\text { camelopardalis }\end{array}$ & 626 & 38 & 6.07 & 1,192 & 58 & 26,272 \\
\hline $\begin{array}{l}\text { Grysbok Raphicerus } \\
\text { sharpei }\end{array}$ & $?$ & 3 & $?$ & 7.5 & 55 & 12 \\
\hline $\begin{array}{l}\text { Hippo Hippopotamus } \\
\text { amphibius }\end{array}$ & $?$ & 2 & $?$ & 1,490 & 58 & 1,728 \\
\hline $\begin{array}{l}\text { Impala Aepyceros } \\
\text { melampus }\end{array}$ & 14,996 & 863 & 5.75 & 60 & 58 & 30,032 \\
\hline $\begin{array}{l}\text { Klipspringer Oreotragus } \\
\text { oreotragus }\end{array}$ & $?$ & 18 & $?$ & 10 & 55 & 99 \\
\hline $\begin{array}{l}\text { Kudu Tragelaphus } \\
\text { strepsiceros }\end{array}$ & 1,297 & 83 & 6.40 & 225 & 57 & 10,645 \\
\hline $\begin{array}{l}\text { Nyala Tragelaphus } \\
\text { angasi }\end{array}$ & $?$ & 7 & $?$ & 108 & 55 & 416 \\
\hline $\begin{array}{l}\text { Sable Hippotragus } \\
\text { niger }\end{array}$ & 221 & 12 & 5.43 & 230 & 55 & 1,518 \\
\hline $\begin{array}{l}\text { Warthog Phacochoerus } \\
\text { aethiopicus }\end{array}$ & 1,804 & 98 & 5.04 & 80 & 54 & 4,234 \\
\hline $\begin{array}{l}\text { Waterbuck Kobus } \\
\text { ellipsiprymnus }\end{array}$ & 762 & 28 & 3.67 & 260 & 55 & 4,004 \\
\hline $\begin{array}{l}\text { Wildebeest } \\
\text { Connochaetes taurinus }\end{array}$ & 5,481 & 198 & 3.61 & 250 & 56 & 27,720 \\
\hline $\begin{array}{l}\text { Zebra Equus burchelli } \\
\text { Total }\end{array}$ & 4,999 & 330 & 6.60 & 320 & 55 & $\begin{array}{r}58,080 \\
215,659\end{array}$ \\
\hline
\end{tabular}

${ }^{1}$ Bothma (2002)

${ }^{2}$ Estes (1991)

communities through the Savé Valley Conservancy Trust (Table 5). Approximately 55,450 $\mathrm{kg}$ will be produced from the planned annual harvest of 60 elephants (Martin, 2007). Depending on the size of the quota, the percentage of meat allocated by ranchers and the human population density in adjacent communal lands, $0.36-2.03 \mathrm{~kg}$ of meat per person per year could be provided to communities in wards adjacent to the Conservancy (Table 6).

\section{Discussion}

Data presented in this study were sourced primarily from surveys, and thus our findings are dependent on the reliability of the answers provided by respondents. Because of the care taken in explaining the purpose of the study to respondents, the match in the cultural background of interviewers and interviewees, the willingness of respondents to participate and answer questions, and the congruence of answers with interviewers' background knowledge of the issues, we believe that the data provided are reliable.

Illegal hunters in the Savé Valley Conservancy area are typically local, poor, unemployed and food-insecure young men who sell bushmeat for money to buy food. Most bushmeat is sold close to the Conservancy to wealthier individuals. The price of bushmeat in the Conservancy area (USD $0.39 \mathrm{~kg}^{-1}$ ) is lower than was recorded in Zimbabwe (USD 1.33) and elsewhere in Africa during the $1990 \mathrm{~s}$ (Tanzania USD 0.76, Botswana 0.85, Zambia 1.32-3.00, 
TABLE 6 Potential elephant meat production and the amount available per person per year, under three scenarios of human population density, for people living in communal lands adjacent to Savé Valley Conservancy, according to variations in quota size and percentage of meat allocated by ranchers.

\begin{tabular}{|c|c|c|c|c|}
\hline Meat source & $\begin{array}{l}\text { Meat produced } \\
(\mathrm{kg})\end{array}$ & $\begin{array}{l}\text { Kg per person } \\
\text { given } 1.7 \% \text { decline in } \\
\text { population since } 1994\end{array}$ & $\begin{array}{l}\text { Kg per person } \\
\text { at } 1994 \text { human } \\
\text { densities }\end{array}$ & $\begin{array}{l}\text { Kg per person given } \\
1.5 \% \text { annual population } \\
\text { growth since } 1994\end{array}$ \\
\hline Elephant cropping & $54,450^{1}$ & 0.58 & 0.46 & 0.36 \\
\hline \multicolumn{5}{|l|}{ Current quotas } \\
\hline Elephant crop plus $16.9 \%$ of trophy quotas ${ }^{2}$ & 90,896 & 0.97 & 0.76 & 0.61 \\
\hline Elephant crop plus $63 \%$ of trophy quotas ${ }^{3}$ & 190,315 & 2.03 & 1.60 & 1.27 \\
\hline \multicolumn{5}{|c|}{ Reduced quotas given recorded illegal hunting } \\
\hline Elephant crop plus $16.9 \%$ of trophy quotas & 86,804 & 0.93 & 0.73 & 0.58 \\
\hline Elephant crop plus $63 \%$ of trophy quotas & 175,058 & 1.87 & 1.47 & 1.17 \\
\hline \multicolumn{5}{|c|}{ Reduced quotas with corrected illegal hunting data ${ }^{4}$} \\
\hline Elephant crop plus $16.9 \%$ of trophy quotas & 82,921 & 0.89 & 0.70 & 0.55 \\
\hline Elephant crop plus $63 \%$ of trophy quotas & 160,548 & 1.71 & 1.35 & 1.07 \\
\hline
\end{tabular}

${ }^{1}$ Martin (2007)

${ }^{2} 16.9 \%$ represents the proportion of meat that ranchers are currently willing to provide to a centralized meat distribution scheme

${ }^{3}$ Ranchers currently use c. $37 \%$ of meat produced from trophy hunting for internal use (personal use, worker rations, tourist lodges and baits for hunting carnivores) and sell $63 \%$. The latter is thus the maximum potential percentage of meat that could be distributed to communities (Lindsey \& Tambling, 2009)

${ }^{4}$ Ranchers in Savé Valley Conservancy estimated that levels of illegal hunting (derived from Lindsey et al., 2011) are 161.5\% worse than reflected in official data

Malawi 0.93, Kenya 0.75, Mozambique 1.00-3.40; Barnett, 1998; Ndibalema \& Songorwa, 2007). Low prices probably reflect weak local purchasing power and the abundant supply of bushmeat. Correspondingly, hunters' earnings from bushmeat (USD $8.19 \mathrm{month}^{-1}$ ) are low (c.f. USD 38 month $^{-1}$ in the Central African Republic, Noss, 1998, and 40.9 month $^{-1}$ in Zambia, Brown \& Marks, 2007).

In African urban markets bushmeat is often an expensive commodity popular for its taste (Barnett, 1998; BowenJones et al., 2003). In the South-East Lowveld, however, and several other Southern and East African rural areas (Barnett, 1998), preference for bushmeat is driven by its affordability (Barnett, 1998). Bushmeat comprises the most important source of protein for both hunters and buyers near Savé Valley Conservancy in the context of chronic food shortages and is utilized by people in $>75 \%$ of households in the study area. However, in keeping with predictions for tropical forest regions (Bennett et al., 2002), wildlife population declines caused by excessive illegal hunting mean that the livelihood benefits are not sustainable (Lindsey et al., 2011).

In recent years Zimbabwe has experienced an unprecedented economic decline (Coltart, 2008). Conditions in the South-East Lowveld are particularly severe: high human densities (11-114 people $\mathrm{km}^{-2}$ ), erratic rainfall, high unemployment and reliance on rain-fed subsistence farming mean that communities are frequently reliant on food aid (Cumming, 2005). However, food aid was disrupted by state-imposed bans on NGOs during the study period, and food availability in stores was reduced by price control policies. Under such harsh economic conditions wildlife populations in Zimbabwe will inevitably be threatened by illegal hunting until food shortages ease and alternative livelihood options arise. However, an economic upturn may not be sufficient to address the bushmeat trade, not least because increased affluence may increase demand for bushmeat (Milner-Gulland et al., 2003; Wilkie et al., 2005).

Illegal hunting provides most of the income for the young men involved and so developing alternative livelihood options is crucial for addressing the problem. The meagre earnings of hunters in the Savé Valley Conservancy area mean that alternative sources of income may be more likely to lure the young men involved into practising alternative livelihood strategies than if hunting was more lucrative (as in Zambia; Brown \& Marks, 2007). The Community Markets for Conservation Project in Zambia provides a potential template for intervention. This project involves provision of technical assistance for communities to increase food-crop yields and provides access through marketing to improved crop prices, and has had success in reducing hunting by participants (Lewis, 2007). The social and ecological issues raised by the bushmeat trade provide overlap between conservation and development agendas, which may make donor funds more accessible (Davies, 2002). A substantial European Union grant was recently allocated to address the bushmeat trade in the South-East Lowveld.

Large-scale illegal hunting in the South-East Lowveld commenced with the settlement of game ranches during land reform (Lindsey et al., 2011). Settlement provided increased access for illegal hunters, as occurs in forests following the construction of logging roads (Barnes, 2002). 
Resettled communities prevented anti-poaching scouts from accessing occupied land, enabling illegal hunters to operate with impunity. The $80 \mathrm{~km}$ of twin $20-25$ wire strand fences that were removed from Savé Valley Conservancy's perimeter during settlement provided a limitless supply of wire for snares. Little land-use planning was conducted and communities were settled without support, training, finance or equipment, and were encouraged to practice rain-fed agriculture on unsuitable land (Lindsey et al., 2008). Low, erratic rainfall and crop damage by elephants mean that crops routinely fail in resettled areas of conservancies (du Toit, 2004). Consequently, resettled farmers in the Conservancy are poorer than established communities on the periphery. Ranches were converted into communal land with open access to wildlife resources. Coordination or control of use of natural resources was unlikely because resettled communities typically comprise artificial groupings of people from varied backgrounds, lacking social cohesion (du Toit, 2004).

Furthermore, resettled communities lack security of tenure over the land they occupy because of the questionable legality of the land acquisition and because of political uncertainty regarding the future of settlement in conservancies (Lindsey et al., 2008). These factors have combined to result in the virtual eradication of wildlife from resettled land and declining populations in adjacent areas (Lindsey et al., 2011). Studies in Central Africa and Kenya have indicated that bushmeat hunting is more prevalent near human settlements and the boundaries of protected areas (Fitzgibbon et al., 1995; Wilkie et al., 1998; Wato et al., 2006) and hunters operating in Savé Valley Conservancy select areas near their home. Realigning land uses in partially resettled areas of the South-East Lowveld is crucial to separate land used for agriculture and for wildlife. Such separation would make protecting wildlife easier and would reduce the extent to which communities incur damages to crops or losses of livestock to wildlife (Lindsey et al., 2008). Some potential for such realignment exists following the development of the wildlife-based land reform policy in 2007, which states that resettled land within conservancies is to be redeveloped for wildlife-based land use through partnerships between those communities, existing landowners, indigenous entrepreneurs and the Parks and Wildlife Management Authority (Lindsey et al., 2008).

Communities neighbouring wildlife areas in the SouthEast Lowveld lack financial stakes in wildlife resources. They commonly bear costs in conflict with wildlife and typically only receive benefits from illegal hunting. Bushmeat hunting is an inefficient form of wildlife utilization, resulting in the loss of $>99 \%$ of the value of animals killed (Lindsey et al., 2011). Alternative means for local people to access benefits from wildlife would thus benefit both communities and private landowners. Steps have been taken to achieve such alternative means. For example, Savé Valley Conservancy is developing a corporate structure that will allocate a $10 \%$ shareholding in the wildlife resource to neighbouring communities such that they will receive annual dividends proportional to the status of wildlife populations in the Conservancy (Lindsey et al., 2008). In addition, the Conservancy has been expanded to incorporate $25 \mathrm{~km}^{2}$ of adjacent land to create a community-owned game ranch from which communities will receive revenues from safari hunting (Lindsey et al., 2008). Experiences from Zambia highlight that for revenues from wildlife-based land use to be effective at reducing illegal hunting, they must be directed appropriately and be sufficient to meet basic household livelihood needs (Lewis, 2007). The CAMPFIRE (Communal Areas Management Programme For Indigenous Resources) programme on communal land in Zimbabwe has achieved some success and, in some areas, the allocation of benefits from safari hunting to communities has reduced illegal hunting and stimulated recoveries in wildlife populations (Child, 2005).

Although extending benefits to communities is important, providing sufficient financial returns to individuals to offset potential gains from illegal hunting is difficult. Consequently, effective anti-poaching will remain important. Increasing expenditure on security can reduce illegal hunting losses, as evidenced by experiences in the Luangwa Valley and Serengeti (Jachmann \& Billiouw, 1997; Hillborn et al., 2006). In Savé Valley Conservancy, although significant investment is made in security (c. USD 180,000 year $^{-1}$; Lindsey et al., 2011), illegal hunters recognize that investment in anti-poaching varies widely among ranches within the Conservancy, creating areas where they can operate with impunity. Furthermore, scouts are underpaid and poorly supervised and consequently commonly collude with and provide assistance to illegal hunters, significantly undermining protection of wildlife.

As in several other Southern African nations (Barnett, 1998), the penal system governing poaching in Zimbabwe is inadequate and not a sufficient deterrent. Most hunters surveyed had been caught before and yet most plan to continue hunting. The value of fines was lower than potential earnings from selling bushmeat, particularly given hyperinflation. The penal system requires adjustment to reflect the value of the wildlife resource. Whereas an individual caught stealing a goat (worth c. USD 20-30) may be granted a sentence of up to 6 years imprisonment (Stock Theft Act, 1959), an individual caught killing a sable antelope Hippotragus niger (worth up to USD 16,000 through trophy fees and daily rates) is likely to receive only a fine of USD 0.60 or 4 months imprisonment.

Communities in and around Savé Valley Conservancy rarely slaughter livestock for food, preferring alternative meat sources for subsistence, as in Central Africa (Wilkie et al., 2005). Meat from domestic stock is expensive in the South-East Lowveld, costing $100-200 \%$ more than bushmeat, as in other parts of Southern and East Africa (Barnett, 
1998). Consequently, illegal bushmeat is commonly the only source of affordable meat. Providing an affordable legal supply of bushmeat may help address illegal trade, particularly if hunters are employed to assist with distribution. By focusing offtake on adult males, legal cropping can produce higher and more sustainable meat yields than unselective harvesting with snares.

A meat distribution programme in Savé Valley Conservancy commenced in 2009, whereby meat from elephants culled there is provided to adjacent communities at a subsidized price. The c. 55 tonnes of elephant meat could be augmented with up to c. 121 tonnes of meat from safari hunting. At present, according to our survey, ranchers are willing to provide $16.9 \%$ of the meat from safari hunting but if the programme is proven to be effective at reducing illegal use and if they are provided with a fair financial return, they would probably provide more. Illegal hunters typically take many hours to transport and then sell meat and so the product for sale is often partially decomposed. In addition, hunters frequently lie to buyers about the species of meat on sale. Consequently, frozen hygienic legal supplies of meat from known species should be attractive to buyers as long as the price is similar to that of meat sold by illegal hunters. Furthermore, safari hunting would yield an abundance of meat from the species preferred by bushmeat buyers.

Wildlife harvesting programmes designed to produce meat for communities have generally failed because of the difficulties associated with identifying the ideal recipients, inadequate supply, lack of financial viability and prohibitive veterinary controls (Barnett, 1998; De Garine \& De GarineWichatitsky, 1999; Holmern et al., 2002; Le Bel et al., 2004). Financial self-sufficiency could be achieved if part of the costs of the meat programme were supported by ranchers as a component of their anti-poaching budgets. Providing an adequate supply of game meat would be challenging, however, because of the high local human population densities. However, the contribution of game meat to protein requirements could be maximized by focusing supply during the time of year when food shortages are most common, during the late dry season and early rainy season, overlapping with the peak in illegal hunting (Lindsey et al., 2011). Focusing meat provision could reduce demand for illegally sourced meat. The provision of affordable game meat from Savé Valley Conservancy would constitute a tangible and recognizable benefit for communities and may improve relationships between communities and private land owners.

Similar programmes could be developed for state, communal or private wildlife areas elsewhere in Africa and particularly those grappling with excessive densities of elephants or with sufficiently high densities of ungulates to support a sustainable harvest. The high, and potentially ecologically harmful, densities of elephants in many South- ern African parks could be turned into an advantage for state wildlife agencies if exploited to provide a sustainable supply of protein for neighbouring communities.

Under conditions of political instability and economic decline in Zimbabwe the illegal bushmeat trade has emerged as a severe threat to wildlife-based land uses. Addressing the trade will be dependent on interventions to rectify the underlying causes, namely poverty, lack of food security, lack of community stakes in wildlife-based land uses, land-use mosaics created by land reform, inadequate investment in anti-poaching enforcement, weak legal deterrents and lack of a legal supply of game meat. Without interventions, and in the absence of political and economic stability in Zimbabwe, wildlife populations will probably continue to suffer intense pressure from illegal hunting.

\section{Acknowledgements}

We are grateful to TRAFFIC East/Southern Africa, the European Union, the German Federal Ministry for Economic Cooperation and Development, Wilderness Trust, Chicago Board of Trade, and the supporters of the African Wildlife Conservation Fund for providing funding, Rueben Bote and Mishek Matari for assistance with field work, and the ranchers of Savé Valley Conservancy for logistical support.

\section{References}

BARnES, R. (2002) The wild meat boom and bust in West and Central Africa. Oryx, 36, 236-242.

B ARnett, R. (1998) Food for Thought: The Utilisation of Wild Meat in Eastern and Southern Africa. TRAFFIC East/Southern Africa, Nairobi, Kenya.

Bennett, E., Blencowe, E., Brandon, K., Brown, D., Burn, R., Cowlishaw, G. et al. (2007) Hunting for consensus: reconciling wild meat harvest, conservation, and development policy in West and Central Africa. Conservation Biology, 21, 884-887.

Bennett, E.L., Milner-Gulland, E.J., Bakarr, M., Eves, H.E., Robinson, J.G. \& Wilkie, D.S. (2002) Hunting the world's wildlife to extinction. Oryx, 36, 328-329.

Bотнма, J. (2002) Game Ranch Management. Van Schaik, Pretoria, South Africa.

Bowen-Jones, E., Brown, D. \& Robinson, E. (2003) Economic commodity or environmental crisis? An interdisciplinary approach to analysing the bushmeat trade in Central and West Africa. Area, 35, 390-402.

Bowen-Jones, E. \& PEndry, S. (1999) The threat to primates and other mammals from the wild meat trade in Africa, and how this threat could be diminished. Oryx, 33, 233-246.

Brown, T. \& MARks, S. (2007) Livelihoods, hunting and the game meat trade in northern Zambia. In Bushmeat and Livelihoods (eds G. Davies \& D. Brown), pp. 92-106. Blackwell, Oxford, UK.

CHIld, B. (2005) Principles, Practice and Results of CBNRM in Southern Africa. Sand County Foundation, Monona, USA. Http:// sandcounty.net/assets/chapters/assets.pdf [accessed 23 September 2008]. 
CiA (Central Intelligence Agency) (2008) The World Factbook. Https://www.cia.gov/library/publications/the-world-factbook/ index.html [accessed 23 September 2008].

Cumming, D. (2005) Wildlife, livestock and food security in the South-East Lowveld of Zimbabwe. In Conservation and Development Interventions at the Wildlife/Livestock Interface: Implications for Wildlife, Livestock and Human Health (eds S.A. Osofsky, S. Cleveland, W.B. Karesh, M.D. Kock, P.J. Nyhus, L. Starr \& A. Yang), pp. 41-45. IUCN, Gland, Switzerland.

Davies, G. (2002) Bushmeat and international development. Conservation Biology, 16, 587-589.

De Garine, I. \& De Garine-Wichatitsky, M. (1999) Providing impala meat to local populations in Nyaminyami (Omay, Zimbabwe). Bois et forets des tropiques, 262, 61-76.

De Merode, E. \& Cowlishaw, G. (2006) Species protection, the changing informal economy, and the politics of access to the bushmeat trade in the Democratic Republic of Congo. Conservation Biology, 20, 1262-1271.

DU Tort, R.F. (2004) Review of Wildlife Issues Associated with the Land Reform Programme in Zimbabwe. WWF-Southern African Regional Programme Office Working Paper No. 10. Harare Zimbabwe.

Estes, R. (1991) The Behavior Guide to African Mammals. University of California Press, Berkeley, USA.

Fa, J., Garcia Yuste, J.E. \& Castelo, R. (2000) Bushmeat markets on Bioko Island as a measure of hunting pressure. Conservation Biology, 14, 1602-1613.

FaO (Food and Agriculture Organization of the United Nations) (2009) FAOSTAT. Http://faostat.fao.org/faostat/help-copyright/ copyright-e.htm [accessed 23 September 2009].

Fitzgibion, C., Mogaka, H. \& Fanshawe, J. (1995) Subsistence hunting in Arabuko-Sokoke Forest, Kenya, and its effects on mammal populations. Conservation Biology, 9, 1116-1126.

Hanke, S. (2009) New Hyperinflation Index Puts Zimbabwe's Inflation at 89.7 Sextillion Percent. Cato Institute, Massachusetts, USA. Http://www.cato.org/zimbabwe [accessed 21 March 2009].

Hatton, J., Couto, M. \& Oglethorpe, J. (2001) Biodiversity and War: A Case Study of Mozambique. WWF Biodiversity Support Program, Washington, USA.

Hillborn, R., Arcese, P., Borner, M., Hando, J., Hopcraft, G., Lоогвокі, M. et al. (2006) Effective enforcement in a conservation area. Science, 314, 126.

Holmern, T., Røskaft, E., Mbaruka, J., Mkama, S. \& Muya, J. (2002) Uneconomical game cropping in a community-based conservation project outside the Serengeti National Park, Tanzania. Oryx, 36, 364-372.

JaChmann, H. \& Billiouw, M. (1997) Elephant poaching and law enforcement in the Central Luangwa Valley, Zambia. Journal of Applied Ecology, 34, 233-244.

Jambiya, G., Milledge, S.A.H. \& Mtango, N. (2007) 'Night Time Spinach': Conservation and Livelihood Implications of Wild Meat Use in Refugee Situations in North-Western Tanzania. TRAFFIC East/Southern Africa, Dar es Salaam, Tanzania.

JMPIN (2000) JMPIN version 4.o.2. SAS Institute, Cary, USA.

Le Bel, S., Gaidet, N., Mutake, S., Le Doze, S. \& Nyamagure, T. (2004) Communal game ranching in Zimbabwe: local empowerment and sustainable game meat production for rural communities. Game and Wildlife Science, 21, 275-290.

LEWIS, D. (2007) Can wildlife and agriculture co-exist outside protected areas in Africa? A hopeful case-study in Zambia. In Bushmeat and Livelihoods (eds G. Davies \& D. Brown), pp. 177-196. Blackwell, Oxford, UK.

LEWis, D. \& Phiri, A. (1998) Wildlife snaring-an indicator of community response to a community based conservation project. Oryx, 32, 111-121.
LindNer, J. (2002) Handling non response error in the Journal of International Agriculture and Extension Education. Journal of International Agriculture and Extension Education, 9, 55-60.

Lindsey, P.A., Romañach, S.S., Tambling, C.J., Chartier, K. \& Groom, R. (2011) Ecological and financial impacts of illegal bushmeat trade in Zimbabwe. Oryx, 45, 96-111.

Lindsey, P., Du Toit, R., Pole, A. \& Romañach, S. (2008) Savé Valley Conservancy: a large scale African experiment in cooperative wildlife management. In Evolution and Innovation in Wildlife Conservation (eds H. Suich, B. Child \& A. Spenceley), pp. 163-184. Earthscan, London, UK.

Lindsey, P. \& Tambling, C. (2009) The Potential Production of Meat from Savé Valley Conservancy. TRAFFIC Report, Harare Zimbabwe.

Loibooki, M., Hofer, H., Campbell, K. \& East, M. (2002) Bushmeat hunting by communities adjacent to the Serengeti National Park, Tanzania: the importance of livestock ownership and alternative sources of protein and income. Environmental Conservation, 29, 391-398.

Martin, R.B. (2007) Savé Valley Conservancy: Management of the Elephant Population. Unpublished Savé Valley Conservancy Report, Chiredzi, Zimbabwe.

Milner-Gulland, E.J., Bennett, E. \& the SCB 2002 Annual Meeting Wild Meat Group (2003) Wild meat: the bigger picture. Trends in Ecology \& Evolution, 18, 351-357.

Ndibalema, V. \& Songorwa, A. (2007) Illegal meat hunting in Serengeti: dynamics in consumption and preferences. African Journal of Ecology, 46, 311-319.

Noss, A. (1998) The impacts of cable snare hunting on wildlife populations of the Central African Republic. Conservation Biology, 12, 390-398.

Okello, M. \& Kiringe, J. (2004) Threats to biodiversity and their implications in protected and adjacent dispersal areas of Kenya. Journal of Sustainable Tourism, 12, 55-69.

Pole, A. (2006) Management Plan for the Savé Valley Conservancy. Unpublished Savé Valley Conservancy Report, Chiredzi, Zimbabwe.

Robinson, J. \& BenNetT, E. (2004) Having your wildlife and eating it too: an analysis of hunting sustainability across tropical ecosystems. Animal Conservation, 7, 397-408.

The IndePendent (2006) Dead by 34: How Aids and Starvation Condemn Zimbabwe's Women to Early Grave. The Independent newspaper, London, UK. Http://www.independent.co.uk/news/ world/africa/dead-by-34-how-aids-and-starvation-condemnzimbabwes-women-to-early-grave-424669.html [accessed 24 September 2009].

UNICEF (2009) Unite for Children. Http://www.unicef.org/ infobycountry/zimbabwe_statistics.html [accessed 23 September 2009].

VAUGHN, C. \& LonG, A. (2007) Bushmeat, wildlife management and good governance: rights and institutional arrangements in Namibia's community based natural resource management. In Bushmeat and Livelihoods (eds G. Davies \& D. Brown), pp. 177-196. Blackwell, Oxford, UK.

Wato, Y., Wahungu, G. \& Okello, M. (2006) Correlates of wildlife snaring patterns in Tsavo West National Park, Kenya. Biological Conservation, 132, 500-509.

Wilkie, D. \& Carpenter, J. (1999) Bushmeat hunting in the Congo Basin: an assessment of impacts and options for mitigation. Biodiversity and Conservation, 8, 927-955.

Wilkie, D., Curran, B., Tshombe, R. \& Morelli, G. (1998) Modelling the sustainability of subsistence farming and hunting in the Ituri forest of Zaire. Conservation Biology, 12, 137-147.

Wilkie, D., Starkey, M., Abernethy, K., Nstame Effa, E., Telfer, P. \& Godoy, R. (2005) Role of prices and wealth in 
consumer demand for wild meat in Gabon, Central Africa.

Conservation Biology, 19, 268-274.

\section{Appendices 1-3}

The appendices for this article are available online at http:// journals.cambridge.org

\section{Biographical sketches}

Peter A. Lindsey's research interests include sustainable utilization of wildlife, the bushmeat trade and developing incentives for land uses conducive to wildlife conservation. S TEPHANIE S. ROMAÑACH works on ecological modelling for restoration of the Everglades, USA, was previously involved in conservation projects in Southern and East Africa, remains involved with projects in Zimbabwe, and helps run the African Wildlife Conservation Fund. Steven Matema is studying competing claims for natural resources in Zimbabwe and has worked on the interface between natural resources and rural African livelihoods, and the social dynamics of the bushmeat trade. Collen Matema's research interests include rural livelihoods and development, natural resource management, market chains analysis, bushmeat trade, household level food gathering strategies and natural resource policy. IsAac Mupamhadzi's research interests include the socioeconomic impacts of climate change, community development, the bushmeat trade and wildlife management. Justic Muvengwi's research interests include linking conservation in protected areas to neighbouring human livelihoods and human-wildlife conflict. 